\title{
Estimation of Trace Element Concentrations in Anti-Epileptic Medicinal Plants by Using EDXRF
}

\author{
N.Giridhar Babu ${ }^{1}$, Ch.Ch.Srinivasu ${ }^{2}$, T.Pothu Raju ${ }^{3}$, N.Lakshmana Das ${ }^{4}$ \\ ${ }^{1,2,3}$ Department of Physics, Acharya Nagarjuna University, Nagarjuna Nagar-522 510, A.P, India \\ ${ }^{4}$ GITAM Institute of Science, GITAM University, Visakhapatnam-530045, A.P, India
}

\begin{abstract}
Trace elemental analysis was carried out in 15 anti-epileptic medicinal plants using Energy Dispersive X-Ray Fluorescence (EDXRF) technique, with EX-3600, EDXRF spectrometer. The quantitative analysis is carried out using the software nEXT. The concentrations of elements like $\mathrm{P}, \mathrm{S}, \mathrm{Cl}, \mathrm{K}, \mathrm{Ca}, \mathrm{Mn}, \mathrm{Fe}, \mathrm{Cu}, \mathrm{Zn}, \mathrm{Br}, \mathrm{Se}, \mathrm{Rb}$, and Sr were estimated. The presence of some of these trace elements is correlated with the anti-epileptic curative property of medicinal plants.
\end{abstract}

Keywords: Trace elements, EDXRF, Epilepsy, Medicinal plants.

\section{Introduction}

The herbal products today symbolize safety in contrast to the synthetics which are regarded as unsafe to human and environment. Although herbs had been praised for their medicinal, flavoring and aromatic qualities for centuries, the synthetic products of the modern age surpassed their importance for a while. Over the past decade, herbal medicine has become a topic of global importance, making an impact on both world health and international trade. In India, drugs of herbal origin have been used in traditional systems of medicines such as Ayurveda and Unani since ancient times. The drugs are derived either from the whole plant or from different organs like leaves, stem, bark, root, flower, seed, etc. Even the allopathic system of medicine has adopted a number of plant-derived drugs which form an important segment of the modern medicine [1]. Use of traditional herbal medicine which is widely prevalent in developing countries, has spread to the industrialized nations also as a complementary way to treat and prevent diseases according to a WHO report [2].

Medicinal plants contain both organic and inorganic constituents. Inorganic trace elements play significant roles; they are intimately involved in the physiological functions and are important co-factors in the production of enzymes. The trace element deficiencies results in the reduced activity of the concerned enzymes. However, since each trace element is related to so many enzymes, deficiency of a single trace element is often not associated with any specific clinical manifestations, but rather manifests as a combination of various symptoms [3]. Relatively less attention was received in research work on inorganic constituents of the medicinal plants than estimation of organic elements. The data obtained on elemental concentrations of the medicinal plants will be helpful in deciding the dosage of herbal medicine prepared using these plant materials [4].

Epilepsy is one of the major brain disorders worldwide. Epilepsy is a disorder of brain electrical activity that results in recurrent seizures. The condition is characterized by repeated seizures or fits. The type of seizure depends on the portion of the brain affected. Patients with epilepsy often require lifelong pharmacotherapy. Current drug therapy of epilepsy is complicated by side-effects, tolerance dependence and long term toxicity [5]. The alternative drug therapy for the management of this disease can be by the use of medicinal plants and their active principles having little or without side effects.

\section{Experimental Details}

\subsection{Sampling}

Fifteen different anti-epileptic medicinal plants (Table 1) were collected from in and around Regional Forest Centre, Rajahmundry, Andhra Pradesh, India. Samples consist of different parts of plants including leaves, aerial parts, roots, fruits and rhizomes. These samples were washed in tap water and rinsed thoroughly with double distilled water in order to remove surface contamination. Each plant sample was then dried, ground and homogenized in an agate mortar. A quantity of $0.2 \mathrm{gm}$ of each powder sample was weighed and compressed using a 150 ton hydraulic press and made into pellets of $13 \mathrm{~mm}$ diameter and about $2 \mathrm{~mm}$ thickness. Triplicates of each sample were done. These pellets were then used as targets for the EDXRF experiment. Biological reference material NIST 1515 (Apple leaf) was used as a reference multi- elemental standard.

The list of medicinal plants selected for present study, their botanical names, code used for representation and the corresponding parts of the plants used for analysis is given in Table 1. The anti-epileptic activity of these plants is clearly documented in literature [6-9].

\subsection{Energy Dispersive X-Ray Fluorescence (EDXRF) analyses}

Several techniques, namely, AAS, PIXE, XRF, ICP-MS, ICP-AES, EDXRF, NAA etc. are generally used for the analysis of elements present in minor quantity down to the level of parts per million or parts per billion. Among these techniques, the energy-dispersive X-ray fluorescence (EDXRF) technique is being widely used for trace element detection in various fields of science. The present study was done using Energy dispersive X-ray fluorescence (EDXRF).

\section{Volume 4 Issue 2, February 2015}




\section{International Journal of Science and Research (IJSR) \\ ISSN (Online): 2319-7064 \\ Index Copernicus Value (2013): 6.14 | Impact Factor (2013): 4.438}

Present study was carried out at trace element laboratory, UGC-DAE CSR Kolkata center, Kolkata. The set-up consists of a Xenemetrix (previously Jordan Valley) EX3600 EDXRF spectrometer. This consists of an X-ray tube with a $\mathrm{Rh}$ anode as the source of X-rays with a $50 \mathrm{~V}, 1 \mathrm{~mA}$ power supply, $\mathrm{Si}(\mathrm{Li})$ detector with a resolution of $143 \mathrm{eV}$ at $5.9 \mathrm{keV}$ and 10-sample turret enables mounting and analyzing 10 samples at a time

Table 1: List of medicinal plants selected for present study with sample codes and parts used.

\begin{tabular}{|c|c|c|}
\hline Sample code & Botanical Name & Part used \\
\hline MP-1 & Glycyrrhiza glabra & Root \\
\hline MP-2 & Centella asiatica & Ariel part \\
\hline MP-3 & Clerodendrum serratum & Root \\
\hline MP-4 & Pongamia pinnata & Leaves \\
\hline MP-5 & Anacyclus pyrethrum & Root \\
\hline MP-6 & Ocimum sanctum & Leaves \\
\hline MP-7 & Acorus calamus & Rhizome \\
\hline MP-8 & Allium sativum & Bulb \\
\hline MP-9 & Tagetes erecta & Flower \\
\hline MP-10 & Sapindus laurifolius & Fruit \\
\hline MP-11 & Asparagus Racemus & Rhizome \\
\hline MP-12 & Vitex negundo & Leaves \\
\hline MP-13 & Nardostachys jatamansi & Root \\
\hline MP-14 & Datura metel & leaves \\
\hline MP-15 & Anisomeles malabarica & Ariel part \\
\hline
\end{tabular}

The targets were positioned at an angle of $45^{0}$ to the beam direction. The X-ray beam was collimated to a diameter of 4 $\mathrm{mm}$ and was made to fall on the target. The detector was kept at an angle of $45^{\circ}$ to the target position and at an angle of $90^{\circ}$ to the X-ray beam direction. The characteristic X-rays emitted from each sample were recorded with a high resolution $\mathrm{Si}(\mathrm{Li})$ detector which has a sensitive area of 30 sq $\mathrm{mm}$ and provided with a thin beryllium window of $8 \mathrm{~mm}$ thickness. The spectra were collected for a sufficiently long time so that good statistical accuracies can be achieved. The quantitative analysis is carried out by using the software $n E X T$.

\section{Results and Discussion}

The results of EDXRF measurements for the determination of the concentration of major, minor and trace elements in medicinal plants are presented in Table 2. Quantitative analysis of thirteen different elements namely, $\mathrm{P}, \mathrm{S}, \mathrm{Cl}, \mathrm{K}$, $\mathrm{Ca}, \mathrm{Mn}, \mathrm{Fe}, \mathrm{Cu}, \mathrm{Zn}, \mathrm{Se}, \mathrm{Br}, \mathrm{Rb}$, and $\mathrm{Sr}$ was done. Many of these elements are of cardinal importance in human metabolism. They are considered essential for the growth of living organisms.

Theoretically, trace elements may play a role in the production of seizures and their control in humans. This concept has led to several studies. Many studies suggested that the body electrolytes, the level of some trace elements, and the membrane lipid per oxidation have been causally involved in some forms of epilepsies and seizure recurrence [10].The equilibrium of trace elements is essential for a healthy nervous system because most of them contribute to the activation of specific enzymes that play important roles in many pathways of the central nervous system. Antioxidative defense mechanism is an important pathway involving trace elements [11]. Certain trace elements and minerals like Magnesium, Zinc, Manganese and others stabilize the nerve cells. Sometimes these materials can show up in the blood or urine, sometimes in mineral analysis of the hair. Often intensive treatment with doses of trace elements can have a very positive effect in reducing the frequency of the convulsions [12].

Limited number of studies has been conducted as regards the role of trace elements and occurrence of seizures. Several researchers reported that the average levels of Zinc, Magnesium, Manganese, Iron, and Selenium in blood serum and hair samples of people afflicted with epilepsy was generally less.

Ulvi et al.(2002) reported that mean values of trace element concentrations of hair in patients were significantly reduced compared with the controls. .H. Avci (2004) reported that the hair of subjects with epilepsy showed significant lower levels of $\mathrm{Cu}$ and $\mathrm{Fe}$ for male and female groups, and $\mathrm{Mg}$ for female group, when compared with control group. Results of $M$. Seven et al (2012) found that the patients with idiopathic intractable epilepsy (IIE) had significantly decreased levels of serum $\mathrm{Se}$ and $\mathrm{Zn}$ compared to those of the control group ( $\mathrm{p}<0.05)$.Fallah $R$ MD(2013) in his work concluded that iron deficiency could be an important risk factor for development of febrile convulsion. Evaluation of iron status is encouraged to be performed in children with febrile seizure. Mahyar et al (2010) reported that serum Selenium level in the case and control groups was $44.4 \pm 10.9$ and 63 $\pm 9.78 \mathrm{mg} / \mathrm{dL}$, a significant difference $(\mathrm{P}<0.001)$. In the case group, $18 / 30$ patients $(60 \%)$ had a serum selenium level below the normal of $46 \mathrm{mg} / \mathrm{dL}$,. The serum Selenium level in the children who had simple febrile seizures was significantly lower than in the non-seizure control group. Results of S. Kumar et al.(2013) indicate that there is an altered immune mechanism in epileptic patients needs a modification in the treatment, which can be maintained by the proper supplementation by trace element like Na, K. Zn, $\mathrm{Fe}, \mathrm{Ca}, \mathrm{Mg}$ and $\mathrm{Cu}$ and the ketogenic diet. Another point of view is that, metals like aluminum, cadmium and lead can release galvanic currents which brain register and converts into epileptic potentials. So administering Manganese, Calcium, Zinc and Selenium which are antagonistic to Aluminum, Cadmium and Lead can be expected to mitigate the adverse effects of metals which release galvanic currents [12].

Deficiency results with reference to epilepsy of some of the trace elements along with recommended daily intake (RDA) values are given in Table 2.

Traditional medicinal practices have remained as a component of health care system of many societies in spite of the availability of well-established alternatives. But focus has shifted to the use of herbal remedies in the management of epileptic seizures, probably because these measures fit into the cultures of people and are not usually expensive and do not possess many side effects, contraindications and possible interactions with drugs used simultaneously.

Zinc is an important element in growth and development of normal brain function and it is also an important co-factor for different enzymes such as DNA and RNA. The 


\section{International Journal of Science and Research (IJSR) ISSN (Online): 2319-7064 \\ Index Copernicus Value (2013): 6.14 | Impact Factor (2013): 4.438}

mechanism by which Zinc in involved in cellular growth and differentiation, enzymatic activity of different organs, proteins and cellular metabolism is well known [13]. The possible role of Zinc deficiency in provoking febrile seizures has been reported in different studies [14]. Some authors have reported that the serum Zinc level in children with febrile seizure is lower than in control group and concluded that this trace element may have a role in febrile seizure [15]. Children with epilepsy have been found to have significantly lower levels of serum Zinc, it appears that people with epilepsy may have elevated Copper-to-Zinc ratio [16]. Seizures may be triggered when Zinc levels fall. Therefore, Zinc supplementation may be warranted.

In the present study, concentrations of Zinc is found to be high in Centella asiatica (93 \pm 2 ppm), Vitex negundo $(48 \pm 1$ ppm), Datura metel (47 \pm 0.6 ppm) and Acorus calamus $(46 \pm 0.3 \mathrm{ppm})$

Selenium depletion in the brain amongst patients with epilepsy may constitute an important triggering factor for the origin of intractable seizures and subsequent neuronal damage [17]. Selenium is an excellent anti-oxidant; various studies have shown that people with epilepsy have significant low levels of selenium and supplementation with Selenium results in fewer seizures $[11,18,16]$.

In the present study, Selenium is found to be slightly high in Anisomeles malabarica $(2.4 \pm 0.6 \mathrm{ppm})$, Anacyclus yrethrum (1.06 \pm 0.7 ppm), Datura metel $(1 \pm 0.6$ ppm $)$
Manganese is an essential trace element required for proper development and functioning of the central nervous system. It has been reported that Manganese is required for activity of glutamine syntheses which converts glutamate to glutamine. However, deficiency of Manganese causes accumulation of glutamate and therefore leads to generation of seizure [19]. Carl et al. (1986) carried out a study in which he compared epilepsy patients with controls and found that Manganese levels in blood were significantly lower in epilepsy patients than in the control group [20,21].

High levels of Manganese are found in Nardostachys jatamansi (371 \pm 4 ppm), Centella asiatica (285 \pm 8 ppm), Datura metel (196 \pm 2 ppm).

Iron deficiency may also a cause for epileptic seizures particularly in children below the age of five years. Based on results of Fallah R MD (2013) and Sadeghzadeh M (2012) study, Iron deficiency and iron deficiency anemia were more frequent in children with febrile seizure and iron deficiency seems to be an important risk factor for the development of febrile convulsion $[22,23]$. Iron is found to be in very high concentrations in Nardostachys jatamansi (4880 \pm 107 ppm), Centella asiatica (3273 \pm 53 ppm), Anisomeles malabarica (1824 \pm 26 ppm)

Table 2: Deficiency results of $\mathrm{Zn}, \mathrm{Mn}, \mathrm{Se}, \mathrm{Fe}, \mathrm{Cu}$, and $\mathrm{Ca}$ with reference to Epilepsy with RDA values

\begin{tabular}{|c|c|c|c|c|c|}
\hline S. No & Elements & $\begin{array}{c}\text { Recommended } \\
\text { daily intake (RDA) }\end{array}$ & $\begin{array}{c}\text { Deficiency results } \\
\text { with reference to epilepsy }\end{array}$ & $\begin{array}{l}\text { No. of samples having } \\
\text { higher concentrations }\end{array}$ & $\begin{array}{c}\text { Range of } \\
\text { concentration }\end{array}$ \\
\hline 1 & $\mathrm{Ca}$ & $500-1100 \mathrm{mg} / \mathrm{d}$ & $\begin{array}{l}\text { Experience tetantic contraction of muscles } \\
\text { throughout the body because of spontaneous nerve } \\
\text { impulses in the peripheral nerves. }\end{array}$ & & $27530-7942 \mathrm{ppm}$ \\
\hline 2 & Mn & $600-2300 \mu \mathrm{g} / \mathrm{d}$ & $\begin{array}{l}\text { Affects cerebral motor function and decrease in } \\
\text { Mn-superoxide dismutase (Mn-SOD) and } \\
\text { glutamine synthesis activity. }\end{array}$ & 6 & $371-95$ ppm \\
\hline 3 & $\mathrm{Fe}$ & $3000-8000 \mu \mathrm{g} / \mathrm{d}$ & $\begin{array}{l}\text { Alterations in synaptic neurotransmitter systems } \\
\text { including norepinephrine, dopamine, serotonin, } \\
\text { glutamate and gamma-amino butyric acid } \\
\text { (GABA). }\end{array}$ & 6 & $4880-621 \mathrm{ppm}$ \\
\hline 4 & $\mathrm{Cu}$ & $\begin{array}{c}260-700 \\
\mu \mathrm{g} / \mathrm{d}\end{array}$ & $\begin{array}{l}\text { Pathological disorders accompanied by convulsive } \\
\text { seizures or tremors. }\end{array}$ & 7 & $19.3-11.6 \mathrm{ppm}$ \\
\hline 5 & $\mathrm{Zn}$ & $2500-9400 \mu \mathrm{g} / \mathrm{d}$ & $\begin{array}{l}\text { Lowering of gamma-amino butyric acid (GABA) } \\
\text { level which can precipitate seizures. }\end{array}$ & 8 & $93.84-33.13 \mathrm{ppm}$ \\
\hline 6 & $\mathrm{Se}$ & $\begin{array}{l}20-55 \\
\mu \mathrm{g} / \mathrm{d}\end{array}$ & $\begin{array}{l}\text { Affects all selenoproteins to different extent and } \\
\text { also effects glutathione peroxidase (GSH-Px) } \\
\text { concentration. }\end{array}$ & 4 & $2.41-0.9 \mathrm{ppm}$ \\
\hline
\end{tabular}

Calcium is a very important mineral for the normal functioning of brain cells, and low levels of Calcium can cause seizures [24]. A deficiency of Magnesium a mineral that interacts with Calcium may cause low blood Calcium and therefore seizures. Total serum Calcium levels were significantly lower in epileptic patients compared with control group [25]. Another point of view is that, Calcium is antagonist to aluminum and Cadmium which can release galvanic currents which brain registers and converts into epileptic potentials. So administering calcium can be expected to mitigate the adverse effects of metals like Aluminum and Cadmium $(4,12)$
In the present study, Concentration of Calcium is found to be high in Datura metel (27530 \pm 75 ppm) and Anisomeles malabarica $(17811 \pm 459 \mathrm{ppm})$.

Magnesium is the fourth most common mineral in the human body and plays an important role in enzyme activities and membrane properties. Recent studies have shown that people with epilepsy have lower $\mathrm{Mg}$ levels than that of people without epilepsy. Also, various in vitro studies have shown that lower magnesium concentration is associated with seizures [26]. The anti-seizure effect of magnesium could also be because of its property to inhibit NMDA receptor. Therefore magnesium supplementation can be

\section{Volume 4 Issue 2, February 2015}




\section{International Journal of Science and Research (IJSR) \\ ISSN (Online): 2319-7064 \\ Index Copernicus Value (2013): 6.14 | Impact Factor (2013): 4.438}

considered for the management of patients with refractory epilepsy [19].

Table 3: Average elemental concentration \pm standard deviation (ppm) of anti-epileptic medicinal plants by EDXRF

\begin{tabular}{|c|c|c|c|c|c|c|c|c|c|c|c|c|c|}
\hline $\begin{array}{l}\text { Sample } \\
\text { code }\end{array}$ & $\mathbf{P}$ & $\mathrm{s}$ & $\mathrm{Cl}$ & $\mathbf{K}$ & $\mathrm{Ca}$ & Mn & $\mathrm{Fe}$ & $\mathrm{Cu}$ & $\mathrm{Zn}$ & $\mathrm{Se}$ & $\mathrm{Br}$ & $\mathbf{R b}$ & $\mathrm{Sr}$ \\
\hline MP-1 & $290=27$ & $1264=59$ & $2869=224$ & $11486=640$ & $9089=391$ & $24.4=1.7$ & $375=23$ & $124=1.6$ & $14.3=0.8$ & $0.13=0.01$ & $2.8=0.5$ & $3.5=0.5$ & $248=22$ \\
\hline MP-2 & $1209=88$ & $341 \varepsilon=251$ & $2320=179$ & $123 \mathrm{a}=288$ & $9626=552$ & $285=10$ & $3273=65$ & $16=1$ & $93=2.8$ & 0.12 & $3.9=0.9$ & $74=3.3$ & $103=5$ \\
\hline MP-3 & $909=57$ & $414=15$ & 579 & $10159=244$ & $\$ 887=305$ & $133=6$ & $1438=69$ & $9.6=0.6$ & $23=0.9$ & $0.6=0.2$ & $26=0.8$ & $8.6=2.2$ & $55=0.3$ \\
\hline MP-4 & $3195=254$ & $2069=79$ & $5313=327$ & $18457=467$ & $3395=77$ & $26=0.9$ & $77=1.5$ & $11=0.5$ & $33=3$ & $0.4=0.04$ & $29=1$ & $9 .=1.8$ & $16=0.7$ \\
\hline MP-5 & $2286=11$ & $1164=16$ & $5862=189$ & $20415=188$ & $6398=48$ & $95=1.7$ & $631=25$ & $83=1$ & $28=1$ & $1.06=0.8$ & $24=1$ & $5.4=1$ & $49=2$ \\
\hline MP- 6 & $2091=129$ & $1425=61$ & $6061=570$ & $6247=130$ & $14484=216$ & $33=2$ & $164=3.5$ & $19=0.6$ & $40=2$ & $0.4=0.2$ & $19 Q=2.5$ & $20=1.6$ & $386=4.7$ \\
\hline MP-7 & $4091=305$ & $4101=165$ & $13350=1383$ & $20040=716$ & $4019=90$ & $43=1.5$ & $621=3$ & $15=0.3$ & $46=0.4$ & $0.16=0.04$ & $12=0.3$ & $9.5=0.6$ & $62=3$ \\
\hline MP-8 & $2990=31$ & $6592=29$ & $1588=13$ & $749 \Leftrightarrow=67$ & $1507=45$ & $13=1$ & $64=4$ & $8.7=0.9$ & $36=1.7$ & $0.3=0.2$ & $6.8=1.7$ & $7.6=0.4$ & $22=1$ \\
\hline MP-9 & $2850=129$ & $1181=60$ & $7015=154$ & $18657=445$ & $3622=158$ & $23=2$ & $173=3$ & $14=1$ & $26=1.7$ & $0.5=0.4$ & $2=0.5$ & $24=2$ & $17=1$ \\
\hline MP-10 & $1137=28$ & $557=23$ & $3491=75$ & $14615=202$ & $2123=8$ & $15=1.7$ & $156=42$ & $6.3=0.8$ & $12.3=1.6$ & 0.13 & $6.6=1$ & $33=1$ & $12=28$ \\
\hline MP-11 & $799=10$ & $2656=65$ & $3480=110$ & $10114=16$ & $5426=210$ & $36=1$ & $249=13$ & $6.8=0.6$ & $13=0.7$ & 0.13 & $2=0.7$ & $5.4=0.8$ & $69=3$ \\
\hline MP-12 & $1745=45$ & $1362=34$ & 579 & $15693=2567$ & $6823=195$ & $49=5$ & $470=10$ & $12.8=0.3$ & $4 \&=1$ & $0.9=0.7$ & 2. $S=0.9$ & $2 \mathrm{~S}=11$ & $16=1$ \\
\hline MP-13 & $391=12$ & $1014=17$ & $57 C=0.5$ & $4138=27$ & $7942=64$ & $371=5$ & $4880=132$ & $8.9=0.2$ & $44=2$ & $0.41=0.4$ & $7.4=1$ & $44=0.2$ & $61=1$ \\
\hline MP-14 & $1663=61$ & $5509=132$ & $3521=98$ & $5491=44$ & $27530=92$ & $196=2$ & $19 c=3$ & $9.7=0.1$ & $47=0.7$ & $1=0.7$ & $187=2$ & $37=2$ & $90=3$ \\
\hline MP-15 & $1369=67$ & $1069=24$ & $3307=254$ & $5975=127$ & $17811=459$ & $182=5$ & $1824=32$ & $9.7=1$ & $24=0.3$ & $2.4=0.7$ & $153=1$ & $30.7=0.5$ & $9 \rho=0.9$ \\
\hline NIST15I5 & 1590 & 1800 & 579 & 16100 & 15260 & 54 & 83 & 5.04 & 125 & 0.05 & 1.8 & 10.2 & 25 \\
\hline
\end{tabular}
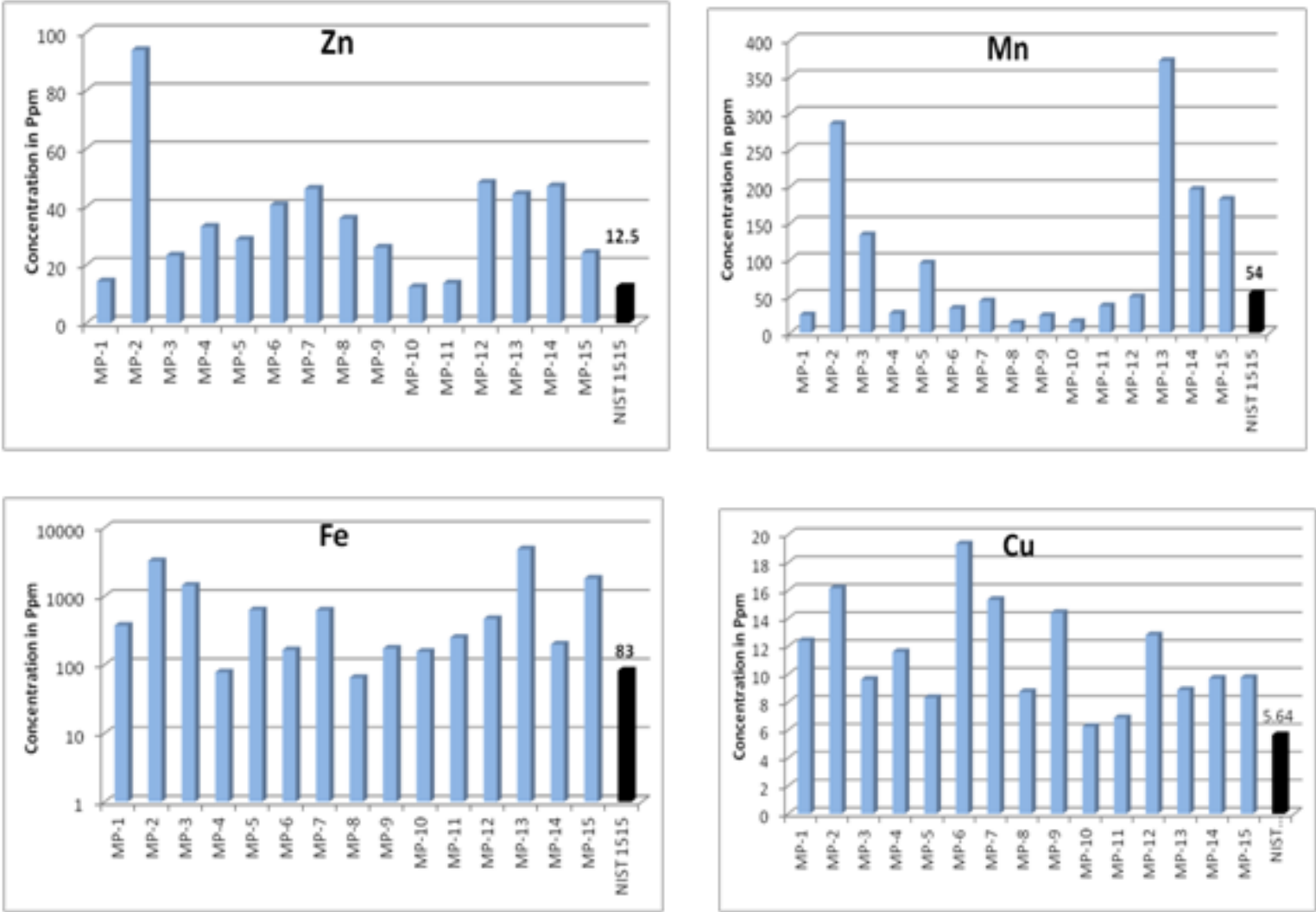

\section{Volume 4 Issue 2, February 2015} www.ijsr.net 
International Journal of Science and Research (IJSR)

ISSN (Online): 2319-7064

Index Copernicus Value (2013): 6.14 | Impact Factor (2013): 4.438
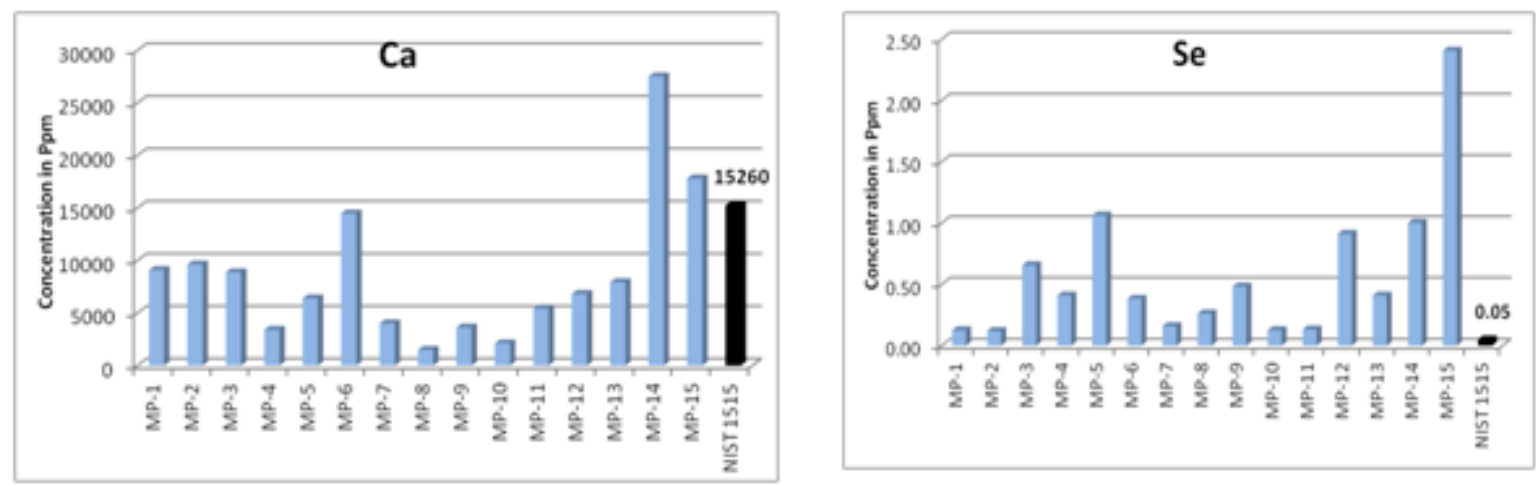

Figure 1: Plots of concentration of $\mathrm{Mn}, \mathrm{Zn}, \mathrm{Fe}, \mathrm{Se}, \mathrm{Ca}$ and $\mathrm{Cu}$ in studied samples with NIST Standard

In present study magnesium is found to be present in most of the samples, but concentration levels are below the detectable range.

Role of copper in epilepsy is still uncertain. Some studies have shown that copper deficiency is more common in patients with epilepsy and have concluded that it could be considered as a causative factor of seizures [27,28,29], whereas, some other studies shown that concentration level of copper is more in epileptic patients than in normal case [30].

In our study, copper is found to be high in Ocimum sanctum (19 \pm 0.6 Ppm) , Centella asiatica (16 \pm 1 ppm), Acorus calamus $(15 \pm 0.3 \mathrm{ppm})$. Along with the aforesaid elements, we also found $\mathrm{P}, \mathrm{K}, \mathrm{Cl}, \mathrm{S}, \mathrm{Br}, \mathrm{Rb}, \mathrm{Sr}$ whose concentrations are tabulated in Table 3 .
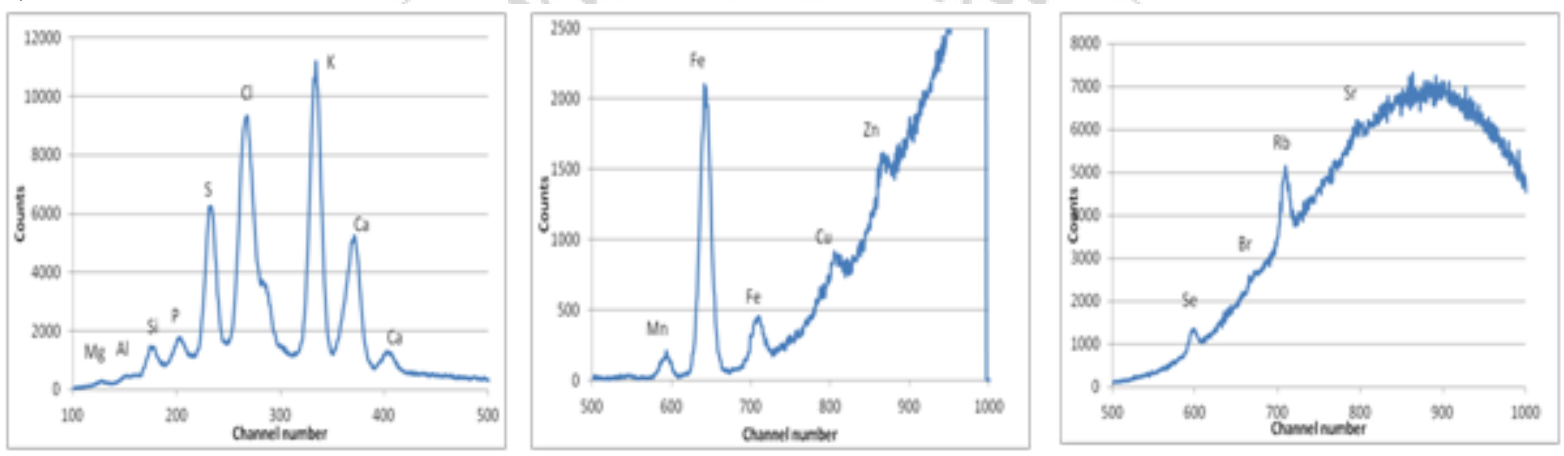

Figure 2: EDXRF spectrums of Asparagus Racemus (MP-11)

\section{Conclusions}

Attempts have been made in the present study to list out various trace elements like $\mathrm{P}, \mathrm{S}, \mathrm{Cl}, \mathrm{K}, \mathrm{Ca}, \mathrm{Mn}, \mathrm{Fe}, \mathrm{Cu}, \mathrm{Zn}$, $\mathrm{Br}, \mathrm{Se}, \mathrm{Rb}$, and $\mathrm{Sr}$ and their concentrations in fifteen different anti-epileptic medicinal plants mentioned in different traditional systems and documented in literature.

Medicinal plants used for the treatment of epilepsy in traditional medicine practice possess promising anticonvulsant activities and these can be an invaluable source for search for new anti-epileptic compounds. Plant based preparations containing these beneficial elements in the form of natural metallo-organic compounds are thought to be superior as they are more effective and have minimal side effects than administering these metals in the form of drugs prepared from chemicals.

The results of the present study provide justification for the usage of these medicinal plants in the treatment of epilepsy, since they are found to contain the elements $\mathrm{Zn}, \mathrm{Se}, \mathrm{Fe}, \mathrm{Mn}$, $\mathrm{Ca}$ and $\mathrm{Mg}$ which contribute to the activation of specific enzymes that play important roles in many pathways of the central nervous system.
Our results show that the analyzed medicinal plants can be considered as potential sources for providing a reasonable amount of the required elements other than diet to the patients of epilepsy. More over, these results can be used to set new standards for prescribing the dosage of the herbal drugs prepared from these plant materials. Still there is some mystification regarding the role of trace elements in epilepsy, so more research in needed in this regard.

The basic data provided here can be utilized for further studies on development of traditional medicine. Phytochemical and harmacological studies of above mentoined plants need to be taken up to find out the exact ingredients that help in different ailments. The data obtained on elemental concentrations of the medicinal plants will be useful in deciding the dosage of Ayurvedic drugs prepared using these plant materials.

\section{Acknowledgements}

The authors are thankful to Dr.A.K.Sinha, Director,UGCDAE-CSR,Kolkata center, for granting the necessary permissions and providing EDXRF facility to carry out the present work. 


\section{International Journal of Science and Research (IJSR) \\ ISSN (Online): 2319-7064}

Index Copernicus Value (2013): 6.14 | Impact Factor (2013): 4.438

\section{References}

[1] Joy, P.P., Thomas, J., Mathew, S., and Skaria, B.P. 2001. Medicinal Plants. Tropical Horticulture Vol. 2. (eds. Bose, T.K., Kabir, J., Das, P. and Joy, P.P.). Naya Prokash, Calcutta, pp. 449-632

[2] WHO (World Health Organization), Traditional Medicine (2003), Fact sheet no. 134

[3] O.Wada, JMAJ 47(8): 351-358, 2004

[4] Sattar, J Radioanal Nucl Chem (2012) 294:337-341

[5] Alan R. Gaby, MD ,Alternative Medicine Review Volume 12, Number 1, March 2007

[6] Harish Babu B. et al.International Journal of Biological \& Pharmaceutical Research.2010; 1(1)1-6.

[7] Singhkaram et al/IJRAP 3(5),Sep-oct 2012

[8] Payal Mittal, Recent Developments on Neurological Diseases, 2013: 129-154

[9] MalviReetesh Ket al IRJP 2(2) 2011 32-39

[10] SA Hamed and MM Abdellah, J Pharmacol Sci 96, 349 - 359 (2004)

[11] Mehmet Sevena Epilepsy Research (2013) 104, 35-39.

[12] Thomas R (2001) Verlag für experimentelle Onkologie GmbH 27316 Hoya. Germany, pp 1-6

[13] A. Mahyar, Acta Medica Iranica 2008; 46(6): 477-480.

[14] Rabbani MW, Ali I, Latif HZ, Basit A, Rabbani MA. Serum Zinc level in children presenting with febrile seizures. Pak J Med Sci 2013;29(4):1008-1011/doi: http://dx.doi.org/10.12669/pjms.294.3464

[15] Hambidge M. Human Zinc deficiency. J Nutr. 2000 May;130(5S Suppl):1344S-1349S.

[16] Farahani et al, Neurosciences 2013; Vol. 18 (2).

[17] Ramaekers VT, Calomme M, Vanden Berghe D, Makropoulos W. Selenium deficiency triggering intractable seizures. Neuropediatrics. 1994;25:217-223.

[18] Mahyar A, Ayazi P, Fallahi M, Javadi A. Correlation between serum selenium level and febrile seizures. Pediatr Neurol 2010;43:331-334.

[19] J. Sancheti, J. Pharm. BioSci. 4(2013) 149-156

[20] Carl, G.F., Keen, C.L., Gallagher, B.B., Clegg, M.S., Littleton, W.H., Flannery, D. Hurley, L.S., 1986. Association of low blood Manganese concentrations with epilepsy. Neurology. 36, 1584-158

[21] Tanaka Y. Low Manganese level may trigger epilepsy. JAMA 1977;238:1805.

[22] Sadeghzadeh M, Khoshnevis P, Mahboubi E. Iron Status and Febrile Seizure- A Case Control Study in Children Less Than3 Years. Iran J Child Neurol Autumn 2012; 6(4): 27-3

[23] Fallah R MD ,Iranian Journal of Pediatric Hematology Oncology Vol3.No1

[24] Thiel R. Might disorders of calcium cause or contribute to myoclonic seizres? Accepted for publication by Medical Hypotheses, November 17, 2005.

[25] Gwenvron M. Griffiths, J Neurol Psychopathol 1934 s1-15,29-38, doi: 10.1136/jnnp.s1-15.57.29

[26] Yuena, A.W., Sander, J.W., 2012. Can magnesium supplementation reduce seizure in people with epilepsy? A hypothesis. Epilepsy Research. 100, 152-6.

[27] Patent US4757059 - Method for treating convulsions and epilepsy with organic copper compounds.

[28] H. Avci ,Trace Elements and Electrolytes, Vol. 25-No. $3 / 2008(147-155)$
[29] Prasad R Journal of Clinical and Diagnostic Research. 2009 Dec;(3)1841-1846

[30] Ulvi H, Eastern journal of medicine 7(2):31-35,2002

Volume 4 Issue 2, February 2015

www.ijsr.net 